\title{
CRISPR/Cas System: A Revolutionary Technique Applied Potentially from Diagnosis to Therapeutics in COVID-19
}

\author{
Roshan Roy ${ }^{1}$, Ashish Srivastava ${ }^{1,2 *}$, Sonal Srivastava ${ }^{1}$, Taruna Gupta ${ }^{1}$, \\ Tripti Singhal' ${ }^{1}$, Prashant Kumar ${ }^{1}$, Sunny Dhir ${ }^{1}$ and Narayan Rishi ${ }^{1}$ \\ ${ }^{1}$ Amity Institute of Virology and Immunology, Amity University Uttar Pradesh, \\ Noida, India \\ ${ }^{2}$ Department of Entomology and Plant Pathology, University of Arkansas, \\ Fayetteville 72701, USA \\ *Corresponding Author: Ashish Srivastava, Department of Entomology and Plant \\ Pathology, University of Arkansas, Fayetteville 72701, USA.
}

Received: November 30, 2021

Published: December 23, 2021

(C) All rights are reserved by Ashish

Srivastava., et al.

\begin{abstract}
The emergence of Coronavirus disease-2019 caused by SARS-CoV-2 has also bought new challenges to the researchers to develop novel therapeutic and diagnostic methods for the pathogen. The preventive vaccines are approved for the public but their role in the development of herd immunity is not clear due to the emergence of new variants of SARS-CoV-2. Therefore, the prime requirement to cope up with the current situation is to develop highly sensitive diagnostics and effective therapeutics to restrict the spread of SARS-CoV-2 among human population. CRISPR/Cas, a talk of the town, is one of the tools that has been used to develop sensitive, rapid and cost-effective diagnostics that may be made available even in the remote areas of the country. The ability of different Cas proteins viz. Cas9, Cas12, and Cas13 in binding and cleaving of dsDNA, ssDNA, and ssRNA, respectively, have been explored for these purposes. The Cas13 based Prophylactic Antiviral CRISPR in huMAN cells (PAC-MAN) and the Specific High-Sensitivity Enzymatic reporter unlocking (SHERLOCK) and Cas 12 based FALUDA technology have already been developed for diagnosis of COVID-19. This review summarizes the role of CRISPR/Cas based approaches for reliable, rapid, and ultrasensitive diagnostics development, and explore the possible therapeutic alternative for combating COVID-19.
\end{abstract}

Keywords: Coronavirus; SARS-CoV-2; Cas13; Diagnosis; Therapeutic; PAC-MAN

\section{Key Points}

- $\quad$ This MS describes information of the emergence of Coronavirus disease-2019 caused by SARS-CoV-2.

- It summarizes and discusses in details about the novel therapeutics and diagnostics developed to date to control this disease.

- $\quad$ Role of CRISPR/Cas is discussed in detail for novel therapeutics and diagnostics development.

\section{Abbreviations}

SHERLOCK: Specific High-Sensitivity Enzymatic Reporter Unlocking; SARS-CoV-2: Severe Acute Respiratory Syndrome Coronavirus 2; PAC-MAN: Prophylactic Antiviral CRISPR in Human Cells

\section{Introduction}

A devastating disease, the COVID-19 has completed one year of its revelation to the world while the scientists and administrators are still making the strategies to get rid of this disease. SARS-CoV-2 (severe acute respiratory syndrome coronavirus 2) Is the causative 
agent of the disease which emerged in Wuhan province of China in late 2019 and was declared as a pandemic in February 2020 by World Health Organization. Phylogenetic analysis of the viral proteins reveal that the virus has evolved from the bat coronavirus, RaTG13, which is evolutionarily linked with Pangolin-CoVs. More than six SARS-CoV-2 strains have been recorded till date with the double mutant virus being the latest circulating strain having one of the most devastating capability. COVID-19 is associated with diverse symptoms including fever, dry cough, tiredness, diarrhea, running nose, bodyache etc which lead to some serious issues such as difficulty breathing or shortness of breath, chest pain, or pressure [1]. So far around 145M cases of COVID-19 disease have been recorded with 3.07M deaths around the globe. United States, India, and Brazil are the top presenters with around $50 \%$ of total cases. Most of the individuals infected with SARS-CoV-2 are either asymptomatic or present mild to moderate symptoms which go away on its own while only a small percentage of affected individuals become critically ill especially if they have other co-morbidities like hypertension, diabetes, cancer etc. (Table 1).

\begin{tabular}{|c|c|c|c|}
\hline S. & Event & Date & Country \\
\hline 1 & $\begin{array}{c}\text { Pneumonia cases were con- } \\
\text { firmed at Wuhan City, Hubei } \\
\text { province, China }\end{array}$ & $\begin{array}{c}\text { December } \\
20,2019\end{array}$ & China \\
\hline 2 & $\begin{array}{c}\text { The Huanan seafood market was } \\
\text { suspected to be the source of the } \\
\text { disease }\end{array}$ & $\begin{array}{c}\text { January 01, } \\
2020\end{array}$ & China \\
\hline 3 & $\begin{array}{c}\text { First death of a 61-year-old male } \\
\text { due to this disease }\end{array}$ & $\begin{array}{c}\text { January 09, } \\
2020\end{array}$ & China \\
\hline 4 & $\begin{array}{c}\text { The Genetic sequence of the } \\
\text { novel coronavirus were released }\end{array}$ & $\begin{array}{c}\text { January 12, } \\
2020\end{array}$ & China \\
\hline 5 & $\begin{array}{c}\text { First imported case of COVID-19 } \\
\text { in Thailand }\end{array}$ & $\begin{array}{c}\text { January 13, } \\
2020\end{array}$ & Thailand \\
\hline 6 & $\begin{array}{c}\text { Imported case of COVID-19 in } \\
\text { Japan }\end{array}$ & $\begin{array}{c}\text { January 16, } \\
2020\end{array}$ & Japan \\
\hline 7 & $\begin{array}{c}\text { First case of COVID-19 in South } \\
\text { Korea }\end{array}$ & $\begin{array}{c}\text { January 20, } \\
2020\end{array}$ & South \\
Korea
\end{tabular}

\begin{tabular}{|c|c|c|c|}
\hline 14 & First case of COVID-19 in Canada & $\begin{array}{c}\text { January 25, } \\
2020\end{array}$ & Canada \\
\hline 15 & $\begin{array}{l}\text { WHO Director-General declared } \\
\text { COVID-19 an outbreak a public } \\
\text { health emergency of interna- } \\
\text { tional concern }\end{array}$ & $\begin{array}{c}\text { January 30, } \\
2020\end{array}$ & $\begin{array}{l}\text { Switzer- } \\
\text { land }\end{array}$ \\
\hline 16 & $\begin{array}{c}\text { First COVID-19 death outside } \\
\text { China }\end{array}$ & $\begin{array}{l}\text { February } \\
02,2020\end{array}$ & $\begin{array}{l}\text { Philip- } \\
\text { pines }\end{array}$ \\
\hline 17 & $\begin{array}{l}\text { COVID-19: the official name of } \\
\text { novel coronavirus was an- } \\
\text { nounced }\end{array}$ & $\begin{array}{l}\text { February } \\
11,2020\end{array}$ & $\begin{array}{l}\text { Switzer- } \\
\text { land }\end{array}$ \\
\hline 18 & $\begin{array}{l}\text { A global research and innovation } \\
\text { forum started in Geneva }\end{array}$ & $\begin{array}{l}\text { February } \\
11,2020\end{array}$ & $\begin{array}{l}\text { Switzer- } \\
\text { land }\end{array}$ \\
\hline 19 & First case of COVID-19 at Egypt & $\begin{array}{l}\text { February } \\
14,2020\end{array}$ & Egypt \\
\hline 20 & First case of COVID-19 at Iran & $\begin{array}{l}\text { February } \\
19,2020\end{array}$ & Iran \\
\hline 21 & First case of COVID-19 at Israel & $\begin{array}{l}\text { February } \\
21,2020\end{array}$ & Israel \\
\hline 22 & $\begin{array}{c}\text { First case of COVID-19 at Leba- } \\
\text { non }\end{array}$ & $\begin{array}{l}\text { February } \\
21,2020\end{array}$ & Lebanon \\
\hline 23 & $\begin{array}{l}\text { First case of COVID-19 at Ku- } \\
\text { wait, Bahrain, Afghanistan, Iraq, } \\
\text { and Oman }\end{array}$ & $\begin{array}{l}\text { February } \\
24,2020\end{array}$ & - \\
\hline 24 & $\begin{array}{l}\text { First case of COVID-19 at Swit- } \\
\text { zerland, Croatia, and Austria }\end{array}$ & $\begin{array}{l}\text { February } \\
25,2020\end{array}$ & - \\
\hline 25 & $\begin{array}{c}\text { First case of COVID-19 at Brazil, } \\
\text { Greece, Georgia, North Mace- } \\
\text { donia, Norway, Romania, and } \\
\text { Pakistan }\end{array}$ & $\begin{array}{l}\text { February } \\
26,2020\end{array}$ & - \\
\hline 26 & $\begin{array}{c}\text { First case of COVID-19 at Ecua- } \\
\text { dor, Qatar, Monaco, and Luxem- } \\
\text { bourg }\end{array}$ & $\begin{array}{l}\text { February } \\
29,2020\end{array}$ & - \\
\hline 27 & $\begin{array}{l}\text { First case of COVID-19 at Czech } \\
\text { Republic, Iceland, and Armenia }\end{array}$ & $\begin{array}{l}\text { March 01, } \\
2020\end{array}$ & - \\
\hline 28 & $\begin{array}{l}\text { First case of COVID-19 at Indo- } \\
\text { nesia, Senegal, Portugal, Andora, } \\
\text { Latvia, Jordan, Morocco, Saudi } \\
\text { Arabia, and Tunisia }\end{array}$ & $\begin{array}{l}\text { March 02, } \\
2020\end{array}$ & - \\
\hline 29 & $\begin{array}{c}\text { First case of COVID-19 at } \\
\text { Ukraine, Argentina, and Chile }\end{array}$ & $\begin{array}{l}\text { March 03, } \\
2020 \\
\end{array}$ & - \\
\hline 30 & First case of COVID-19 at Poland & $\begin{array}{l}\text { March 04, } \\
2020 \\
\end{array}$ & Poland \\
\hline 31 & $\begin{array}{l}\text { First case of COVID-19 at Bosnia } \\
\text { and Herzegovina, Slovenia, } \\
\text { South Africa, and Palestine }\end{array}$ & $\begin{array}{l}\text { March 05, } \\
2020\end{array}$ & - \\
\hline 32 & $\begin{array}{l}\text { First case of COVID-19 at Slo- } \\
\text { vakia, Bhutan, Peru, Costa Rica, } \\
\text { Columbia, Cameroon, and Togo }\end{array}$ & $\begin{array}{l}\text { March 06, } \\
\quad 2020\end{array}$ & - \\
\hline 33 & $\begin{array}{c}\text { First case of COVID-19 at Malta, } \\
\text { Moldova, Paraguay, and the } \\
\text { Maldives }\end{array}$ & $\begin{array}{l}\text { March 07, } \\
2020\end{array}$ & - \\
\hline 34 & $\begin{array}{l}\text { First case of COVID-19 at Bul- } \\
\text { garia and Bangladesh }\end{array}$ & $\begin{array}{l}\text { March 08, } \\
2020\end{array}$ & - \\
\hline
\end{tabular}




\begin{tabular}{|c|c|c|c|}
\hline 35 & $\begin{array}{l}\text { First case of COVID-19 at Alba- } \\
\text { nia, Cyprus, Burkina Faso, and } \\
\text { Panama }\end{array}$ & $\begin{array}{l}\text { March 09, } \\
2020\end{array}$ & - \\
\hline 35 & $\begin{array}{c}\text { First case of COVID-19 at Brunei } \\
\text { Darussalam, Democratic Repub- } \\
\text { lic of Congo, Bolivia, Jamaica, } \\
\text { and Mongolia }\end{array}$ & $\begin{array}{l}\text { March 10, } \\
\quad 2020\end{array}$ & - \\
\hline 36 & $\begin{array}{l}\text { First case of COVID-19 at Turkey, } \\
\text { Côte d'Ivoire, Cuba, Guyana, } \\
\text { Honduras, Saint Vincent, and the } \\
\text { Grenadines }\end{array}$ & $\begin{array}{l}\text { March 11, } \\
2020\end{array}$ & - \\
\hline 37 & $\begin{array}{c}\text { First case of COVID-19 at } \\
\text { Trinidad and Tobago, Ghana, and } \\
\text { Gabon }\end{array}$ & $\begin{array}{l}\text { March 12, } \\
2020\end{array}$ & - \\
\hline 38 & $\begin{array}{l}\text { First case of COVID-19 at Ka- } \\
\text { zakhstan, Sudan, Puerto Rico, } \\
\text { Venezuela, Antigua and Bar- } \\
\text { buda, Ethiopia, Guinea, Kenya, } \\
\text { Uruguay, Guatemala, St. Lucia, } \\
\text { Suriname, and Mauritania }\end{array}$ & $\begin{array}{l}\text { March 13, } \\
2020\end{array}$ & - \\
\hline 39 & $\begin{array}{l}\text { First case of COVID-19 at Na- } \\
\text { mibia, Central African Republic, } \\
\text { Republic of Congo, Equatorial } \\
\text { Guinea, Rwanda, Seychelles, and } \\
\text { Eswatini }\end{array}$ & $\begin{array}{l}\text { March 14, } \\
2020\end{array}$ & - \\
\hline 40 & $\begin{array}{l}\text { New York SARS-CoV-2 Real-time } \\
\text { Reverse Transcriptase (RT)- } \\
\text { PCR Diagnostic kit approved } \\
\text { and First case of COVID-19 at } \\
\text { Uzbekistan and the Bahamas }\end{array}$ & $\begin{array}{l}\text { March 15, } \\
2020\end{array}$ & USA \\
\hline 41 & $\begin{array}{l}\text { First case of COVID-19 at Soma- } \\
\text { lia, Benin, Liberia, and Tanzania }\end{array}$ & $\begin{array}{l}\text { March 16, } \\
2020\end{array}$ & - \\
\hline 42 & $\begin{array}{l}\text { First case of COVID-19 at Mon- } \\
\text { tenegro, Barbados, Gambia, and } \\
\text { Montserrat }\end{array}$ & $\begin{array}{l}\text { March 17, } \\
2020\end{array}$ & - \\
\hline 43 & $\begin{array}{l}\text { First case of COVID-19 at } \\
\text { Kyrgyzstan, Djibouti, Zambia, El } \\
\text { Salvador, and Nicaragua }\end{array}$ & $\begin{array}{l}\text { March 18, } \\
2020\end{array}$ & - \\
\hline 44 & $\begin{array}{l}\text { First case of COVID-19 at Mauri- } \\
\text { tius, Fiji, Chad, Niger, and Haiti }\end{array}$ & $\begin{array}{l}\text { March 19, } \\
2020\end{array}$ & - \\
\hline 45 & $\begin{array}{c}\text { First case of COVID-19 at Papua } \\
\text { New Guinea, Cape Verde, Zimba- } \\
\text { bwe, and Madagascar }\end{array}$ & $\begin{array}{l}\text { March 20, } \\
\quad 2020\end{array}$ & - \\
\hline 46 & $\begin{array}{l}\text { First case of COVID-19 at East } \\
\text { Timor, Angola, and Eritrea }\end{array}$ & $\begin{array}{l}\text { March 21, } \\
2020\end{array}$ & - \\
\hline 47 & $\begin{array}{c}\text { First case of COVID-19 at } \\
\text { Uganda, Grenada, Mozambique, } \\
\text { Dominica, and Syria }\end{array}$ & $\begin{array}{l}\text { March 22, } \\
\quad 2020\end{array}$ & - \\
\hline 48 & $\begin{array}{l}\text { First case of COVID-19 at Myan- } \\
\text { mar and Belize }\end{array}$ & $\begin{array}{l}\text { March 23, } \\
\quad 2020\end{array}$ & - \\
\hline 49 & $\begin{array}{l}21 \text { days lockdown in India and } \\
\text { First case of COVID-19 at Libya } \\
\text { and Laos. }\end{array}$ & $\begin{array}{l}\text { March 24, } \\
2020\end{array}$ & India \\
\hline
\end{tabular}

\begin{tabular}{|c|c|c|c|}
\hline 50 & $\begin{array}{l}\text { First case of COVID-19 at Saint } \\
\text { Kitts and Nevis, Guinea-Bissau, } \\
\text { British Virgin Islands, and Mali }\end{array}$ & $\begin{array}{l}\text { March 25, } \\
2020\end{array}$ & - \\
\hline 51 & $\begin{array}{l}\text { First case of COVID-19 at Saint } \\
\text { Kitts and Nevis, Guinea-Bissau, } \\
\text { British Virgin Islands, and Mali }\end{array}$ & $\begin{array}{l}\text { March 25, } \\
2020\end{array}$ & - \\
\hline 52 & $\begin{array}{l}\text { Johnson and Johnson announced } \\
\text { the selection of a lead COVID-19 } \\
\text { vaccine candidate. }\end{array}$ & $\begin{array}{l}\text { March 30, } \\
\quad 2020\end{array}$ & USA \\
\hline 53 & $\begin{array}{l}\text { COVID-19 ELISA IgG Antibody } \\
\text { Test approved }\end{array}$ & $\begin{array}{l}\text { April 15, } \\
2020\end{array}$ & USA \\
\hline 54 & $\begin{array}{l}\text { CRISPR-based strategy for RNA- } \\
\text { guided viral RNA inhibition and } \\
\text { degradation (PAC-MAN) }\end{array}$ & $\begin{array}{l}\text { May 14, } \\
2020\end{array}$ & USA \\
\hline 55 & $\begin{array}{l}\text { RT-LAMP AQ-TOP COVID-19 } \\
\text { Rapid Detection Kit approved }\end{array}$ & $\begin{array}{l}\text { May 21, } \\
2020\end{array}$ & USA \\
\hline 56 & $\begin{array}{c}\text { SARS-CoV-2 DETECTR Reagent } \\
\text { Kit }\end{array}$ & $\begin{array}{l}\text { August 31, } \\
2020\end{array}$ & USA \\
\hline 57 & $\begin{array}{c}\text { The Russian Direct Investment } \\
\text { Fund submitted applications for } \\
\text { WHO prequalification Sputnik V } \\
\text { vaccine, }\end{array}$ & $\begin{array}{l}\text { October 27, } \\
2020\end{array}$ & Russia \\
\hline 58 & $\begin{array}{l}\text { U.K. government approves first } \\
\text { COVID-19 vaccine candidate } \\
\text { from Pfizer and BioNTech for } \\
\text { domestic use }\end{array}$ & $\begin{array}{c}\text { December } \\
02,2020\end{array}$ & $\begin{array}{l}\text { United } \\
\text { Kingdom }\end{array}$ \\
\hline 59 & $\begin{array}{l}\text { The U.K. begins to roll out the } \\
\text { Pfizer-BioNTech vaccine use }\end{array}$ & $\begin{array}{c}\text { December } \\
08,2020\end{array}$ & $\begin{array}{c}\text { United } \\
\text { Kingdom }\end{array}$ \\
\hline 60 & $\begin{array}{l}\text { The Pfizer-BioNTech COVID-19 } \\
\text { vaccine receives regulatory ap- } \\
\text { proval in Canada }\end{array}$ & $\begin{array}{c}\text { December } \\
09,2020\end{array}$ & USA \\
\hline 61 & $\begin{array}{l}\text { U.S. FDA gives emergency use } \\
\text { authorization to the Pfizer-BioN- } \\
\text { Tech COVID-19 vaccine }\end{array}$ & $\begin{array}{l}\text { December } \\
11,2020\end{array}$ & USA \\
\hline 62 & $\begin{array}{c}\text { The U.S. begins to roll out a mass } \\
\text { COVID-19 vaccination campaign } \\
\text { with the Pfizer-BioNTech vac- } \\
\text { cine. }\end{array}$ & $\begin{array}{c}\text { December } \\
14,2020\end{array}$ & USA \\
\hline 63. & $\begin{array}{l}\text { The COVID-19 vaccine was } \\
\text { launched for the first group in- } \\
\text { cludes healthcare and frontline } \\
\text { workers. }\end{array}$ & $\begin{array}{c}\text { January 16, } \\
2021\end{array}$ & India \\
\hline 64. & $\begin{array}{l}\text { After over a year, Israel de- } \\
\text { cleared mask free through suc- } \\
\text { cessful vaccination program. }\end{array}$ & $\begin{array}{l}\text { April 20, } \\
2021\end{array}$ & Israel \\
\hline 65. & $\begin{array}{l}\text { India recorded highest COV- } \\
\text { ID-19 cases }(314,835) \text { in a day. }\end{array}$ & $\begin{array}{l}\text { April 23, } \\
2021\end{array}$ & India \\
\hline 66. & $\begin{array}{l}\text { India recorded } 14 \text { million CO- } \\
\text { VID-19 vaccine doses in a day. }\end{array}$ & $\begin{array}{l}\text { August 31, } \\
2021\end{array}$ & India \\
\hline 67. & $\begin{array}{l}\text { India become first country to } \\
\text { administered } 7.3 \text { billion doses }\end{array}$ & $\begin{array}{c}\text { September } \\
11,2021 \\
\end{array}$ & India \\
\hline 68. & $\begin{array}{l}\text { Omicron (B.1.1.529): SARS- } \\
\text { CoV-2 Variant of Concern }\end{array}$ & $\begin{array}{l}\text { November } \\
24,2021\end{array}$ & $\begin{array}{l}\text { South } \\
\text { Africa }\end{array}$ \\
\hline
\end{tabular}

Table 1: Showing the various Timeline of Covid-19. 
Although several vaccines have been developed against SARSCoV- 2 with efficacy ranging from $65 \%$ to more than $90 \%$, their efficacy is compromised due to emergence of new variants of the virus. With the emergence of these new variants, the virus is spreading at an alarming rate with a very high reproductive number and infectivity rate of almost $25 \%$ in India. Since most of the cases are asymptomatic, the best way to contain the spread of this virus is early detection and prevention of its spread at individual level in the community. Simultaneously, availability of effective and specific antiviral therapy is also important for reducing the mortality rate among critically ill individuals. The popular clustered regularly interspaced short palindromic repeats (CRISPR) and CRISPR-associated (Cas) proteins-based techniques are playing important roles in the development of point-of-care-testing (POCT) and therapeutics for COVID-19 disease [5]. The need for surveillance of SARS-CoV-2 accelerates research in the field of Nucleic acid-based testing (NAT) based diagnostics to develop inexpensive, rapid, and ultrasensitive kits. NAT tools proved ultrasensitive and accurate diagnostics for multiplexed virus infection thus major attempts being performed to convert typical diagnostics into nucleic acid POCT tools. From the earliest case of COVID-19 disease, the use of qRT-PCR (quantitative, real-time reverse-transcription polymerase chain reaction) was recommended worldwide, however, the testing requires expensive infrastructure and trained manpower. These limitations proved insufficient to surveillance the spread of the disease. The popular POCT techniques such as Recombinase Polymerase Amplification (RPA) and Loop-Mediated Isothermal Amplification Based Assay (LAMP), could not be proved as efficient as qRT-PCR. Therefore, multiplexing of CRISPR/Cas was studied along with these isothermal amplification techniques to improve the reliability of the diagnosis $[6,7]$. This review article deals will explain the overall advances of the CRISPR/Cas system towards COVID-19 disease surveillance and therapeutics (Figure 1).

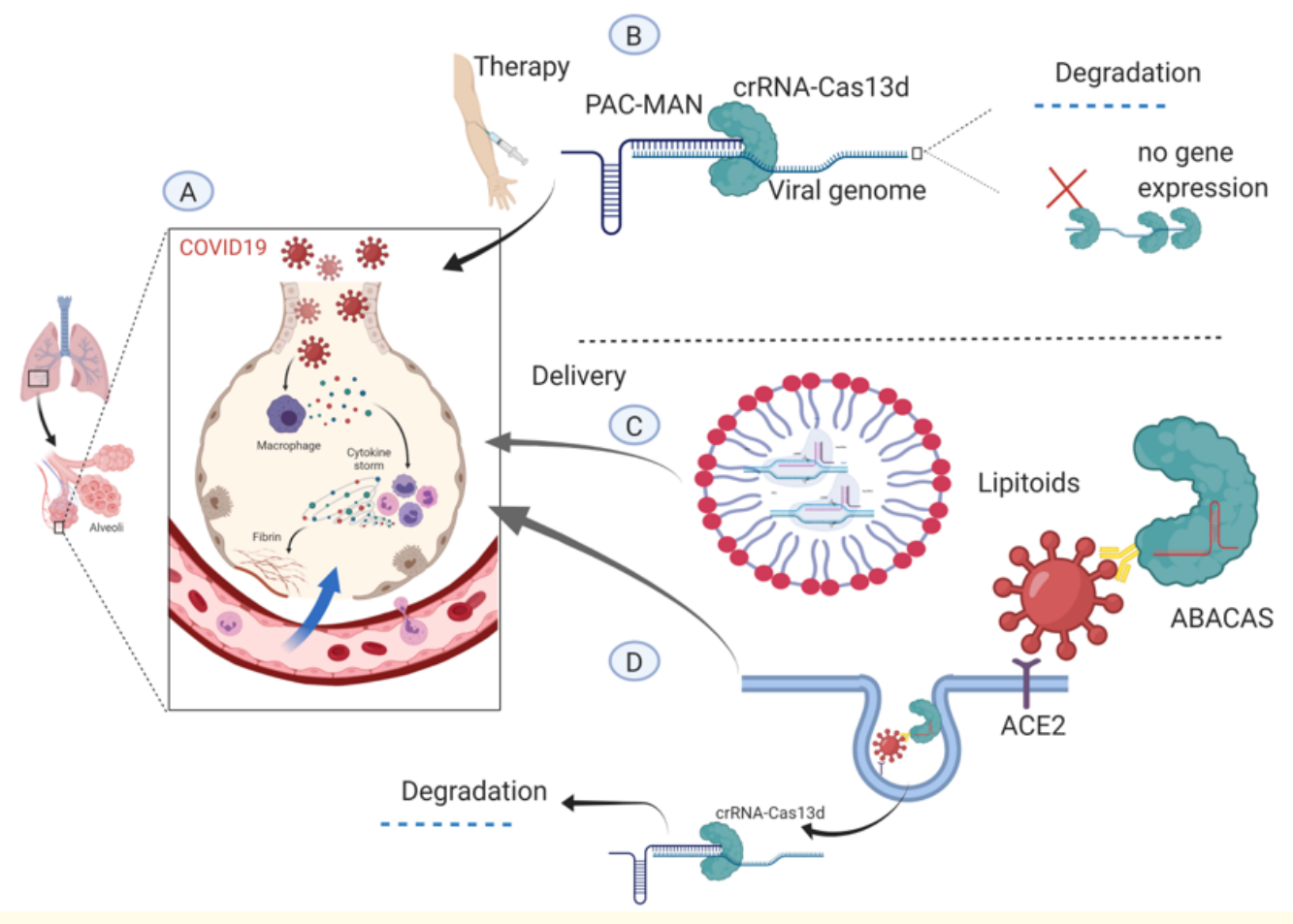

Figure 1: Overview of CRISPR based therapeutics and their delivery systems for COVID19 (Created with BioRender.com) (A). SARS-CoV-2 upon entry to pulmonary niche via ACE2 triggers cytokine storm that leads to acute respiratory distress syndrome (ARDS). (B). Prophylactic Antiviral CRISPR in the huMAN cells (PAC-MAN) is a CRISPR-Cas13d-based intervention developed by Abbott., et al. is capable of degrading viral genome or blocking the expression of essential genes with dead Cas13 (C). Lipitoid 1 mediated delivery of PAC-MAN is highly efficient solution to delivery problems. (D). Novel delivery system suggestions like fusion of Cas13 with antibody fragment specific to $S$ protein of virus [AntiBody And CAS fusion (ABACAS)] can also be very efficient in delivering CRISPR components to specific infected locations.

Coronavirus disease 2019 (COVID-19)

The $21^{\text {st }}$ century is known for the advances in technologies of communications such as smartphones, and medical devices such as ultrasound, advanced diagnostic systems, and genetic engineering which made human beings safer. However, the emergence of new diseases in this century and the inability of the human being 
to handle them shows that we are still far behind to control an emerging or re-emerging disease. Since the first report of human coronavirus infection in 1960s, seven viruses have emerged which have the potential to cause mild to severe disease in human population. In the past 20 years itself, human beings have witnessed the emergence of highly pathogenic coronaviruses ( $\mathrm{CoV}$ ) viz. SARS$\mathrm{CoV}$, MERS-CoV and SARS-CoV-2. The Severe Acute Respiratory Syndrome Coronavirus (SARS-CoV) emerged in 2003 in Guangdong, China while the Middle East Respiratory Syndrome Coronavirus (MERS-CoV) emerged in 2012 in Saudi Arabia [8,9]. Although SARS-CoV and MERS-CoV didn't cause pandemic, they had a very high mortality rate of $10 \%$ and $35 \%$ respectively which is much higher as compared to the mortality rate observed in the ongoing COVID-19 pandemic.

\section{Taxonomy of SARS-CoV-2}

SARS-CoV-2 belongs to subfamily Orthocoronavirinae in the Coronaviridae family under the order Nidovirales. There are four genera viz. Alphacoronavirus, Betacoronavirus, Gammacoronavirus and Deltacoronavirus in this subfamily and SARS-CoV-2 belongs to Betacoronavirus genus. The genus is further subdivided into five subgenera viz. Embecovirus, Hibecovirus, Merbecovirus, Nobecovirus, and Sarbecovirus and SARS-CoV-2 forms a discrete lineage in Sarbecovirus subgenus.

\section{Structural features of SARS-CoV-2}

SARS-CoV-2 has a crown-shaped appearance due to uniform distribution of spike proteins on the virion surface as observed under electron microscope. It is an enveloped virus having a nonsegmented positive sense ssRNA genome of $\sim 30 \mathrm{~kb}$. The genome encodes four structural proteins viz. spike protein(S), envelope protein $(\mathrm{E})$, Nucleoprotein $(\mathrm{N})$ and Matrix membrane protein (M) in addition to six accessory and sixteen non-structural proteins. The trimeric spike glycoprotein is responsible for host cell tropism and entry into the target cells via ACE2 receptor. The spike glycoprotein has two subunits (S1 and S2) and shows a structural difference from the spike protein of other similar coronaviruses in having a typical furine like cleavage site (S1/S2) rich in basic amino acid residues (SPRRARSVAS) which favors its efficient entry of virus into host cells.

\section{Transmission}

The incubation period for SARS-CoV-2 ranges from two to fourteen days with a median incubation period of 5-6 days but an infected individual starts shedding the virus before the onset of symptoms or even if he or she is asymptomatic. Transmission of SARS-CoV-2 primarily occurs via aerosols exhaled by an infected individual leading to an airborne transmission. The virus can also be transmitted to a healthy individual via fomites carrying the virus or by direct contact between an infected and healthy individual.
During the first wave of pandemic in 2020, individuals above 65 years of age or those having co-morbities like hypertension, diabetes, cancer, sthma etc were more prone to infection with SARSCoV-2 but the second wave of pandemic in India has revealed a different scenario. The double mutant reported in the country along with Brazillian strain, UK strain and South African strain equally affects the young adults and children. The transmissibility rate has almost doubled with the $\mathrm{R}_{0}$ value upto 5.4 .

\section{Clinical symptoms}

Individuals infected with SARS-CoV-2 may be asymptomatic carrier or may exhibit mild, moderate or severe ARDS. The patients usually show symptoms like high fever above $102^{\circ} \mathrm{F}$, headache, dry cough, sore throat, chest congestion, chest pain, shortness of breath, loose motion, running nose, redness in eyes etc. In severe cases, the patients may show the respiratory rate above $30 / \mathrm{min}$, oxygen saturation in blood below $95 \%$ and in this critical stage, severe pneumonia, septic shock, respiratory failure, cardiac arrest and multiple organ failure may occur leading to death of individual. The fatalities during SARS-CoV-2 infection could be attributed to ARDS which occurs primarily due to cytokine storm resulting from abnormal immune response and excess release of pro-inflammatory cytokines in lungs.

\section{Diagnosis of COVID-19}

Molecular and serological assays are available for the diagnosis of COVID-19. Though the specimen required for these tests depends on the clinical presentations in affected individuals but respiratory specimens are the most common specimen for the diagnosis of SARS-CoV-2 infection. Nucleic acid amplification test (NAAT) is the most accurate test available for the diagnosis of COVID-19 and it involves procedures like sample collection, sample processing, RNA extraction, real time RT-PCR and its analysis. As far as possible, the patients suspecting SARS-CoV-2 infection should get diagnosed based on rRT-PCR. Amplification of more than one target on SARSCoV-2 genome is needed for accurate diagnosis of the viral infection. The commonly used rRT-PCR targets in SARS-CoV-2 include the Envelop gene (E). Nuceloprotein gene (N), RNA dependent RNA Polymerase (RdRP) gene and Spike protein (S) gene. Owing to enhanced rate of mutation in the viral genome, at least three of the mentioned targets must be included in the diagnosis to avoid any false negative results. Recently, fully automated NAAT system has been developed that integrates the processes like sample processing, RNA extraction, amplification and reporting. These automated systems can be installed in remote resource limited areas with limited numbers of high performance trained staffs.

Additionally, other amplification methods for detection of SARS-CoV-2 are under development or under the process of commercialization. These methods involve the technologies like Re- 
verse Transcription Loop-Mediated Isothermal Amplification (RT-LAMP), Clustered Regularly Interspersed Short Palindromic Repeats (CRISPR) and molecular microarray assays.

The serological assay includes the detection of viral protein in respiratory tract specimen. These are rapid tests which are based on Lateral Flow Immunoassays (LFI) and can be completed within 30 minutes, however, the sensitivity of LFI based rapid tests are lesser as compared to NAAT. Moreover, chances of false positive results also exist with the rapid tests if the antibodies on test strip cross-reacts with the antigen on viruses than SARS-CoV-2.

\section{Vaccines}

Considerable efforts have been put for the development of ef- fective vaccines against SARS-CoV-2 infection. Vaccines that are being developed to tackle COVID-19 are inactivated vaccines and subunit vaccines including mRNA and DNA vaccines targeting the spike protein of the virus. According to World Health Organization (WHO), seven different vaccines have been released in various countries (Table 2) and vulnerable populations are being given priority for vaccination. Apart from this, approximately 200 vaccine candidates are under development, out of which 60 are under clinical evaluation. Though vaccination, as a prophylactic measure, is the best way to protect the population against SARS-CoV-2 infection, mutation in the viral genome is a big challenge to the vaccination drive. However, the vaccinated individual is always at a lower risk as compared to unvaccinated individuals in terms of the disease severity.

\begin{tabular}{|c|c|c|c|}
\hline Name of Vaccine & Vaccine Type & Primary Developers & Country of Origin \\
\hline $\begin{array}{c}\text { Comirnaty (BNT162b2) } \\
\text { (mRNA-1273) }\end{array}$ & mRNA-based vaccine & Pfizer, BioNTech; Fosun Pharma & Multinational \\
\hline $\begin{array}{c}\text { Moderna COVID19 Vaccine } \\
\text { (AZD1222); also known as } \\
\text { Vaxzevria and Covishield }\end{array}$ & mRNA-based vaccine & Moderna, BARDA, NIAID & US \\
\hline $\begin{array}{c}\text { Sputnik V } \\
\text { COVID-19 Vaccine AstraZeneca }\end{array}$ & $\begin{array}{c}\text { Recombinant adenovirus } \\
\text { vaccine (rAd26 and rAd5) }\end{array}$ & $\begin{array}{c}\text { Gamaleya Research Institute, Acellena Contract } \\
\text { Drug Research and Development }\end{array}$ & UK \\
\hline $\begin{array}{c}\text { COVID-19 Vaccine Janssen } \\
\text { (JNJ-78436735; Ad26.COV2.S) }\end{array}$ & $\begin{array}{c}\text { Non-replicating viral vector } \\
\text { EpiVacCorona }\end{array}$ & Janssen Vaccines (Johnson and Johnson) & The Netherlands, \\
\hline US
\end{tabular}

Table 2: Vaccines approved for SARS-CoV-2.

\section{Therapeutics for COVID-19}

Pathogenesis of SARS-CoV-2 infection involves two processes viz. replication of SARS-CoV-2 in the tissues of host organisms in early stage of infection and abnormal/exaggerated host immune response in late stage of infection. Therefore, the therapeutics to treat COVID-19 depends on the stage of disease. Antibody based therapy may be more suitable when the patient displays mild or moderate symptoms and disease progression needs to be stalled to prevent hospitalization during early stage. Two monoclonal antibodies viz. Bamlanivimab and the combination of casirivimab and imdevimab have received Emergency Use Authorization by FDA for treatment of outpatients suffering from COVID-19.

In the advanced stage of disease, Remdesivir, which is an antiviral agent, along with Dexamethasone can be used to treat hospi- talized patients. Other combination of drugs prescribed for SARSCoV-2 infected patients include Paracetamol, Hydroxychloroquine, Ivermectin, and Doxycyclin.

\section{Establishment of the CRISPR/Cas system:}

The CRISPR-Cas (Clustered Repeat Interspaced Short Palindromic Repeats/CRISPR Associated Proteins) system is derived from the adaptive immune response which is commonly found in bacteria and archaea to combat the bacteriophage infection. The prokaryotic immune system is adapted upon the presence of foreign viral genome material entering into the cell. As a memory of the victory, their system incorporates the parts of the genome of the invading bacteriophage into their specific loci and transcribes the resulting loci into the guide RNA to ultimately destroy the virus on re-entry [14]. The CRISPR/Cas system contains an endonucle- 
ase and a CRISPR array that carries a dual-RNAs, tracrRNA:crRNA, for site-specific and programmable DNA cleavage. The CRISPR array of genes consists of the leader sequence (an AT-rich sequence), repeats, and spacer sequences (crRNA). The Cas 9 protein has six domains, the remodeling of the recognition (REC) I and II, Bridge Helix, PAM Interacting region, $\mathrm{HNH}$, and RuvC domains [15]. The largest Rec I domain works as a site for binding guide RNA while the REC II domain in off-target discrimination [16]. The PAM-Interacting domain is held responsible for the binding to target DNA while the bridge helix help in the initiation of the cleavage post target DNA binding. The HNH and RuvC domains are the nuclease domains that create nicks in the single-stranded DNA [17].

The CRISPR Cas systems are majorly classified into two classes; the Class 1 system (type I, III, IV) and the Class 2 system (type II, V, VI). the Class 1 system (type I, III, IV). The class 1 system imparts immunity by forming an effector complex of multi-subunit crRNA and the Class 2 CRISPR Cas system (type II, V, VI) imparts immunity by a single subunit of crRNA. The major Cas proteins used for therapies and diagnosis of SARS-CoV-2 are Cas9, Cas12, and Cas13 [5]. Cas9 requires a trans-activating CRISPR RNA (tracrRNA) and guided by single-guide RNA (sgRNA) and in the presence of PAM sequence in the host, this protein creates a double-stranded break in the dsDNA $[5,18]$. The most popular CRISPR-associated protein 9 is the Streptococcus pyogenes Cas9 (SpCas9) which recognizes the 5' NGG 3' as PAM sequence in a host and the Francisella novicida Cas9 (FnCas9) which recognizes 5' NGG 3' as PAM sequence $[19,20]$. Since the activated Cas 9 works by cleaving the target and cause silencing of the genes to the next generation, therefore, development of a new Cas9 with mutated nuclease domains that is dCas9 (nuclease deficient Cas9) can be a good step to bind at the transcription site of the desired section of a gene. These two features of Cas 9 and dCas 9 were explored for the diagnosis of SARSCoV-2 [21].

The activity of cleaving the target DNA creates double-stranded breaks which need to reseal for normal replication to occur. The sealing of the DNA usually occurs through two pathways (i) nonhomologous end joining (NHEJ) and the homology directed repeat (HDR) [22]. These two in vitro mechanisms are studied to edit genomes either by knocking out of genes or knocking in sequences of interest. Another class of Cas protein (Class 2 type V) is Cas12 (Cpf1), which is known to target and create cuts in both dsDNA as well as the ssDNA. Cas12 works with a CRISPR RNA (crRNAs) and possesses the cis and trans cleavage activity of ssDNA which is being used for the SARS-CoV-2 diagnostic kit preparations. The research on RNA phages leads to the discovery of a new class of CRISPR-associated protein, Cas13 (C2c2) nuclease which has a specific recognition and cleavage activity for complementary RNA and once activated also cleaves nearby trans RNA [23]. This feature is first utilized to develop diagnostic played an important role in the diagnosis of viruses and other mRNAs in vitro.

\section{CRISPR/Cas based methods for SARS-CoV-2 diagnosis}

At the onset of COVID-19 in the globe, the biggest limiting factor to treat the disease was the unavailability of the easy and POCT molecular diagnostic kits. qRT-PCR based kits were majorly recommended by the WHO (World Health Organization) for early diagnosis of the disease, however, the suitability of such kits is restricted due to the requirement of specialized instruments and trained manpower. Simultaneously, the serological POCT kits were having limitations with their sensitivity and accuracy [24]. Therefore, the major research groups around the world were focused on CRISPR/ Cas based rapid and ultrasensitive diagnostic kits for the SARSCoV-2 and recommended their suitability for surveillance of SARSCoV-2 strains. Researchers have explored different properties of Cas9, Cas12, and Cas13 proteins in addition to various isothermal amplification technology to develop reliable, ultrasensitive, and rapid diagnostics.

The story of CRISPR/Cas-based diagnostics was started with Nucleic acid Sequence-based Amplification based CRISPR cleavage (NASBACC) with the use of Cas9 to detect Zika virus strains in vitro. In this method, the isolated RNA of ZIKA virus was amplified by isothermal amplification technique, NASBA, and detected through paper-based sensors [25]. In India, the first dCas9 based kit for SARS-CoV-2 diagnostic kit 'Feluda' was developed and approved for commercial use by the Drugs Controller General of India (DGCI). The FnCas9 Editor Linked Uniform Detection Assay (FELUDA) kit was developed by the use of dCas 9 which selectively binds to target DNA without nicking it. To detect a SARS-CoV-2 genome, the Fluorescein amidites (FaM)-tracr RNA-sgRNA and anti-FAM antibody conjugate with nanoparticles and a paper-based Lateral flow assay device was developed for the field-based diagnosis of SARS-CoV-2 outbreaks [26]. 
The type V CRISPR associated effector protein, Cas12 is commonly explored for CRISPR based diagnostics development. Cas12a protein needs one CRISPR RNA (crRNA) without tracrRNA and cleaves dsDNA by RuvC domain, and once activated, it can cleave nearby ssDNA and RNA in trans, therefore, most suitable for diagnosis (Table S1) [27]. The system was assembled with some isothermal systems and the lateral flow devices as well as the fluorimeter-based detection system. The Cas12a-based system utilizes ssDNA probes in place of RNA probes, therefore, are more stable in field conditions. With the identification of the role of Cas12 in collateral cleavage of ssDNA, the HOLMES (one-HOur Low-cost Multipurpose highly Efficient System) and the DETECTR (DNA Endonuclease Targeted CRISPR Trans Reporter) techniques were established for pathogen detection [28]. The CRISPR/Cas12based detection was demonstrated for SARS-CoV-2 by utilizing DETECTR assay and it was claimed as a visual and faster alternative to the COVID-19 qRT-PCR assay [29]. In the past few months, several new techniques were established for the detection of the SARS-CoV-2 genome in nasal swab samples with the role of Cas 12 proteins. The All-in-One Dual CRISPR-Cas12a (AIOD-CRISPR) and iSCAN (in vitro Specific CRISPR-based Assay for Nucleic acids detection) are two important systems that were explored for the diagnosis of the SARS-CoV-2 [30,31]. These techniques utilize the collateral cleavage activity of ssDNA probes to cleave nearby DNA probes. AIOD-CRISPR operates with a pair of crRNAs that initiate dual CRISPR-Cas12a detection, therefore, it improves the detection sensitivity of the COVID-19 pathogen. While the AIOD-CRISPR is a one-pot LAMP-based system, which detects the SARS-CoV-2 genome in an ultrasensitive and reliable manner. Since Cas12 targets amplified DNA sequences and do not requires extra RNA transcription steps, therefore, this system gets popular over all the available techniques. A new system, ENHanced Analysis of Nucleic acids with CrRNA Extensions (ENHANCE) is also introduced for SARS-CoV-2 genome detection, which is based on an extended $3^{\prime}$ or $5^{\prime}$-ends of the crRNA with different lengths of ssDNA, ssRNA, and phosphorothioate ssDNA. This detection system can measure up to the femtomolar range without any target pre-amplification step [32]. Recently, Srivastava et al (2022) has proposed a new Collateral Cleavage Independent CRISPR/Cas12a based detection system (CCI-CRISPR) for plant viruses [50].

The use of CRISPR/Cas as a detection system was popularized after the successful introduction of the specific high-sensitivity enzymatic reporter unlocking (SHERLOCK) system which har- nesses the quality of collateral cleavage of RNA by Cas13 for the diagnosis of viral genomes [33]. The SHERLOCK system showed its potential during the outbreak of the SARS-CoV-2 and a modified

\begin{tabular}{|c|c|c|}
\hline S. No. & Bacterial Strain & Cas12a \\
\hline 1. & Francisella tularensis & FnCas12a \\
\hline 2. & Acidaminococcus sp. & AsCas12a \\
\hline 3. & $\begin{array}{c}\text { Lachnospiraceae } \\
\text { bacterium }\end{array}$ & LbCas12a, Lb5Cas12 \\
\hline 4. & Oribacterium sp & OsCas12a \\
\hline 5. & Helcococcus kunzii & HkCas12a \\
\hline 6. & Thiomicrospira sp & TsCas12a \\
\hline 7. & Bacteroidales $\mathrm{sp}$. & BbCas12a, BoCas12a \\
\hline 8 & $\begin{array}{c}\text { Lachnospiraceae } \\
\text { bacterium }\end{array}$ & LbCas12a \\
\hline
\end{tabular}

Table S1: List of bacterial strains standardized for HOLMES (one-Hour Low-cost Multipurpose highly Efficient System) based diagnostic assay (Li., et al. 2018).

protocol COVID-19 diagnosis was established [34]. Another Cas13 based method for SARS-CoV-2 diagnosis, Rugged, Equitable, Scalable Testing (CREST) is introduced which is claimed to be a lowcost technique without sacrificing detection sensitivity [35]. The Combinatorial Arrayed Reactions for Multiplexed Evaluation of Nucleic acids (CARMEN) technique is also based on Cas13, which is a highly multiplexed method for SARS-CoV-2 molecular detection [36] (Table 3).

\section{CRISPR/Cas based methods for COVID-19 therapeutics}

Unlike vaccines which in principle train the immune system to fight the invading pathogen and unlike drugs that generally develop resistance, especially in case of highly mutating viruses. The CRISPR based therapeutics directly target the viral genome or mRNA and perform degradation or inactivation of effector functions. Therefore, the outcome of the CRISPR based therapeutic interventions highly rely upon the identification of pathogen-specific conserved genome or coding sequence responsible for important pathogenesis mechanisms. Utilizing in-depth knowledge of these basics, Abbott., et al. have developed Prophylactic Antiviral CRISPR in the huMAN cells (PAC-MAN) approach by identifying a pool of six CRISPR RNAs bio-informatically that can target $90 \%$ coronaviruses with $90 \%$ efficiency. Derived from Ruminococcus flavefaciens XPD3002, this CRISPR-Cas13d-based intervention effectively in- 


\begin{tabular}{|c|c|c|c|c|c|c|}
\hline Nuclease & Platform & $\begin{array}{l}\text { Isothermal } \\
\text { Amplification } \\
\text { method }\end{array}$ & $\begin{array}{l}\text { Detection } \\
\text { method }\end{array}$ & sgRNA target & Mechanism & References \\
\hline Cas9 & FELUDA & RPA/ PCR & $\begin{array}{c}\text { Paper-based LF } \\
\text { device }\end{array}$ & $\begin{array}{l}\text { Genome of SARS- } \\
\text { CoV-2 }\end{array}$ & $\begin{array}{c}\text { gRNA-dFnCas9 RNP complexes } \\
\text { with target DNA and detected } \\
\text { colorimetric LF device }\end{array}$ & $\begin{array}{l}\text { Azhar., et al. } \\
2020\end{array}$ \\
\hline \multirow[t]{4}{*}{ Cas12 } & DETECTR & LAMP & $\begin{array}{c}\text { Paper-based LF } \\
\text { device }\end{array}$ & $\begin{array}{l}\text { Nucleoprotein } \\
\text { and Envelop gene } \\
\text { of SARS-CoV-2 }\end{array}$ & $\begin{array}{l}\text { Cas12a-crRNA complex binds } \\
\text { and cleave a dsDNA, and de- } \\
\text { tects fluorescence in collateral } \\
\text { cleaved probe DNA }\end{array}$ & $\begin{array}{l}\text { Broughton } \\
\text { et a., } 2020\end{array}$ \\
\hline & AIOD-CRISPR & PCR & $\begin{array}{l}\text { LED blue light } \\
\text { illuminator }\end{array}$ & $\begin{array}{l}\text { complete N gene } \\
\text { of SARS-CoV-2 }\end{array}$ & $\begin{array}{c}\text { One-pot collateral cleavage re- } \\
\text { action system and colorimetric } \\
\text { detection }\end{array}$ & $\begin{array}{l}\text { Ding., et al. } \\
2020\end{array}$ \\
\hline & iSCAN & LAMP & $\begin{array}{l}\text { Fluorescence } \\
\text { visualization in } \\
\text { UV light and LF } \\
\text { device }\end{array}$ & $\begin{array}{l}\text { Nucleoprotein } \\
\text { and Envelop gene } \\
\text { of SARS-CoV-2 }\end{array}$ & $\begin{array}{l}\text { CRISPR-Cas12a based collateral } \\
\text { cleavage and fluorescence- } \\
\text { based detection }\end{array}$ & $\begin{array}{l}\text { Ali., et al. } \\
\quad 2020\end{array}$ \\
\hline & ENHANCE & LAMP & $\begin{array}{l}\text { fluorescence- } \\
\text { based and a } \\
\text { paper-based } \\
\text { lateral flow assay }\end{array}$ & $\begin{array}{l}\text { SARS-CoV-2 N- } \\
\text { gene }\end{array}$ & $\begin{array}{l}\text { the modified crRNAs in a pa- } \\
\text { per-based LFA that can detect } \\
\text { the target with up to } 23 \text {-fold } \\
\text { higher sensitivity. }\end{array}$ & $\begin{array}{l}\text { Nguyen., et } \\
\text { al. } 2020\end{array}$ \\
\hline \multirow[t]{3}{*}{ Cas13 } & SHERLOCK & RPA & $\begin{array}{c}\text { Fluorescence } \\
\text { spectrophotom- } \\
\text { eter/Paper based } \\
\text { LF device }\end{array}$ & $\begin{array}{l}\text { SARS-CoV-2 N- } \\
\text { gene }\end{array}$ & $\begin{array}{l}\text { crRNA/ Cas13 targets an ssRNA } \\
\text { and cleaved fluorescent ssRNA } \\
\text { probe collaterally }\end{array}$ & $\begin{array}{l}\text { Joung., et al. } \\
2020\end{array}$ \\
\hline & CREST & RPA/ PCR & $\begin{array}{c}\text { Fluorescence } \\
\text { spectrophotom- } \\
\text { eter/Paper based } \\
\text { LF device }\end{array}$ & $\begin{array}{l}\text { SARS-CoV-2 nu- } \\
\text { cleocapsid gene }\end{array}$ & $\begin{array}{l}\text { Cas13 activation followed by } \\
\text { visualization with blue LED and } \\
\text { orange filter. }\end{array}$ & $\begin{array}{c}\text { Rauch., et al. } \\
2020\end{array}$ \\
\hline & CARMEN & PCR & $\begin{array}{l}\text { Fluorescence } \\
\text { spectrophotom- } \\
\text { eter }\end{array}$ & $\begin{array}{l}\text { SARS-CoV-2 } \\
\text { genomic parts }\end{array}$ & $\begin{array}{c}\text { SHERLOCK method in one } \\
\text { array enables more than } 4500 \\
\text { nucleic acids. }\end{array}$ & $\begin{array}{l}\text { Ackerman., } \\
\text { et al. } 2020\end{array}$ \\
\hline
\end{tabular}

Table 3: Various CRISPR associated protein-based diagnostic platforms for SARS-CoV-2.

hibits the infection by degrading two conserved regions coding for RNA-dependent RNA polymerase (RdRP) gene and Nucleocapsid (N) gene of synthetic SARS-CoV-2 infected human lung epithelial cells in in-vitro settings by measuring pathogen-associated gene expression and GFP reporter signal repression. Since live strains of COVID-19 were not available, the group tested the proof of concept by targeting conserved regions of neuraminidase (NA) of H1N1 IAV live infection in human lung epithelial cells and found the results showing similar trends in reduction of viral load [37]. In a similar direction, Nguyen., et al. have designed 10,333 guide RNAs targeting ORF1a/b which codes for the RdRP gene and the spike (S) gene
[38]. In-effective delivery systems, however, make these studies lack data from in-vivo studies, possible immune responses, side effects, and clinical trials.

CRISPR-Cas13 is a Class 2 type VI CRISPR-associated RNAguided RNA nuclease, this version of Cas is independent of PAM and thus offers higher flexibility. Studies show that CRISPR-Cas13 is capable of effective suppression of gene expression at the post-transcriptional level in about $24 \mathrm{~h}$ of time [39], thus marking the potential of Cas13 to inhibit the coronavirus infection at the post-transcriptional level also. Further, a smaller size of 967 
amino acids helps Cas13 to get easily packed in gene therapy vector AAV (Adeno-associated virus) over conventional methods like electroporation, lipofection, and microinjection. With a sgRNA size requirement of $20 \mathrm{bp}$ and $\mathrm{AAV}$, this system is capable of targeting more than one region of SARS-CoV-2 very efficiently [38]. In comparison to Cas 9 which generates lethal off-target effects like cancer by generating DNA breaks that are repaired by Non-Homologous End Joining (NHEJ) repair, Cas13 is safe, since it functions at the RNA level. Further, usage of catalytically inactive dead Cas13 can help to block the activation of essential polyproteins without cutting the RNA. However, this easy-to-use, highly specific, sensitive, and the cost-effective tool has lacked the attention of clinicians due to side effect concerns and the unavailability of efficient delivery systems. Since it is now possible to cultivate SARS-CoV-2, utilizing the virus only expressing $\mathrm{S}$ and $\mathrm{N}$ proteins as the delivery vectors can also have potential benefits [40].

Major issues with even highly efficient delivery methods like $A A V$ are that they are less efficient in delivery and deliver components non-specifically to both infected and uninfected cells, increasing chances of off-target activity. Thus, there is a need for selective and efficient CRISPR component delivery systems. In this line, Dhanusha and Kusal., et al. suggest a fusion of Cas13 with antibody fragment specific to $\mathrm{S}$ protein of virus [AntiBody And CAS fusion (ABACAS)] can be an approach for specific delivery of component to infected cell In addition to this, studies have also shown that lipid means like lipofection and petide means like lipitoids can act as effective delivery systems for CRISPR. Lipitoids are synthetic peptide mimics (peptoid) capable of encapsulating the nucleotides in nanoparticles that have a size similar to a virus. In this direction, a group of researchers from Stanford have conducted studies by combining lipitoid 1 and PAC-MAN technologies together, which proved to be highly effective in human lung cells, this combination further reduced the concentration of synthetic SARS-CoV-2 by greater than $90 \%$. Moreover, the group now aims to replicate this approach in animal models and if proven successful they further aim to scale up the experiments for pre-clinical procedures [41].

Similar to gene therapy, cell therapy is also a novel and advanced therapeutic intervention in the CRISPR era. Mesenchymal Stem Cells (MSCs) are a highly popular choice for cell therapy with their easy source availability, less reported adverse effects, high proliferative index, few invasive procedures, and free from ethical issues. Further, COVID19 is associated with cytokine storm which is dam- aging by its inflammatory nature, MSCs can be highly beneficial in this case, with their regeneration, repair, and immune-modulatory properties, which can help in repairing or regenerating the alveolar epithelial cells and cure lung dysfunction [42]. Since they can be isolated from many sources and stored for longer periods, they make into list of potential COVID19 therapeutics. Clinical studies show that MSCs cell therapy has shown remarkably positive recovery of lung condition in H5N1 infection, thus increasing the hopes for similar results for COVID infection, with many MSCs cell therapy candidates permitted clinical trials [43]. Early results from this cell therapy are very promising for COVID19 with significant improvement in health and an increase in CD4+ and CD8+ T cell population [44]. Further, MSCs are ACE2- and TMPRSS2- [42], which means they are free from infection, thus making them safe and effective candidates. The ability of CRISPR to regulate the cell behavior at the genome level by genetic and epigenetic modifications, at the transcriptional level by editing and silencing mechanisms, makes it a very favorable tool in the cell therapy field. In this line, MSCs can be edited by CRISPR to act as immune modulators to repair the pathological damage, for instance, induced expression of antiinflammatory genes in MSCs used for arthritis cell therapy [45]. Likewise, CRISPR can help delay telomere shortening by epigenetic modifications and delay the senescence of these stem cells, thereby prolonging the therapeutic effect [46]. These immune-modulation and prolonged therapeutic activities can be highly beneficial for MSCs used for SARS-CoV-2 therapy (Figure 1).

Since viruses are highly evolving species, there is a high need for an antiviral platform that is self-adaptable. Cas13-assisted Viral Expression and Readout (CARVER) is one such platform that combines mechanisms of Cas13 nuclease and Cas 13 based SHERLOCK diagnosis, this development is programmed to kill the RNA viruses in human cells. The effectiveness of this strategy was tested on LCMV, VSV, and IAV infections, which marked CARVER as a strong diagnostic and therapeutic tool [47].

\section{Conclusion and Future Prospects}

The twenty-first century is considered the golden time of Medical sciences research, however, SARS-CoV-2 emerged as a big challenge to researchers from the whole world. The limitations with the diagnostics infrastructure and therapeutics remained insufficient to prevent the spread of the disease. However, the emergence of the CRISPR/Cas technique in parallel proved as a blessing in dis- 
guise. The technique proved equally powerful in the development of molecular diagnostics as well as potential therapeutics. Unlike the qRT-PCR based techniques where a well-established infrastructure and trained manpower required, the CRISPR/Cas based technique such as SHERLOCK, DETECTR, FELUDA, CARMEN showed their strength in the field of reliable and rapid POCT detection of SARS-CoV-2. Approval of Cas 9 based 'Feluda' and Cas13 based 'SHERLOCK' for public use suggests that the CRISPR/Cas system may prove the better alternative for qRT-PCR based kits.

With successful applications of CRISPR in gene therapy and the FDA approval for clinical trials for Retinal gene therapy, researchers find a good future for CRISPR based technologies in the future [48]. With more and more cutting-edge technologies like CARVER, PAC-MAN, and delivery systems like Lipitoids being developed by research society, there have been continuous efforts to overcome concerns over the efficiency of CRISPR therapeutics. Looking ahead to the future, these novel strategies are advanced alternatives to fight pandemics like COVID19 than traditional drugs and vaccines, which some-times fails with cases of resistance and re-infections or short-lived immunity [49], respectively.

\section{Funding}

Department of Science and Technology, New Delhi (DST-INSPIRE-Faculty scheme, IFA-17-LSPA-100) to AS; Indian Council of Medical Research, New Delhi (ICMR- File No. 5/3/8/29/ITRF/2020) to AS, TG; and the University Grant Commission, New Delhi, India (UGC) to SS (795/CSIR- UGC NET JUNE 2017).

\section{Conflicts of Interest}

There is no competing interest.

\section{Availability of Data and Material}

Data is available with the communicating authors and can be presented on demand.

\section{Code Availability}

Not applicable.

\section{Ethics Approval}

This review article doesn't require Ethics approval. All the participants have agreed to this publication.

\section{Authors' Contributions}

AS and NR developed the concept. RR, AS, SS, PK and TG have written the MS. RR and SS prepared the figure. AS and PK finalized the draft.

\section{Consent to Participate}

All the authors have given consent for the participation of this MS.

\section{Consent for Publication}

All the authors have given consent for the publication of this MS.

\section{Bibliography}

1. K Dhama., et al. "An update on SARS-CoV-2/COVID-19 with particular reference to its clinical pathology, pathogenesis, immunopathology and mitigation strategies". Travel Medicine and Infectious Disease 37 (2020): 101755.

2. S Zaim., et al. "COVID-19 and Multiorgan Response". Current Problems in Cardiology 45 (2020): 100618.

3. KG Andersen., et al. "The proximal origin of SARS-CoV-2". Nature Medicine 26 (2020): 450-452.

4. YS Malik., et al. "Emerging novel coronavirus (2019-nCoV)current scenario, evolutionary perspective based on genome analysis and recent developments". Veterinary Quarterly 40 (2020): 68-76.

5. P Kumar., et al. "CRISPR-Cas System: An Approach with Potentials for COVID-19 Diagnosis and Therapeutics". Frontiers in Cellular and Infection Microbiology 10 (2020): 639.

6. Srivastava T., et al. "Next-Generation Rapid Advanced Molecular Diagnostics of COVID-19 by CRISPR-Cas". Diagnostic Strategies. COVID-19 Other Coronaviruses. Medical Virology from Pathogenesis to Disease Control (2020): 175-187.

7. S Srivastava., et al. "Next-Generation Molecular Diagnostics Development by CRISPR/Cas's tool: rapid detection and surveillance of viral disease outbreaks". Frontiers in Molecular Biosciences (2020).

8. MA Shereen., et al. "COVID-19 infection: Origin, transmission, and characteristics of human coronaviruses". Journal of Advanced Research 24 (2020): 91-98. 
9. R-H Xu., et al. "Epidemiologic clues to SARS origin in China". Emerging Infectious Diseases 10 (2004): 1030-1037.

10. F Li. "Receptor Recognition Mechanisms of Coronaviruses: a Decade of Structural Studies". Journal of Virology 89 (2015).

11. M Pal., et al. "Severe Acute Respiratory Syndrome Coronavirus-2 (SARS-CoV-2): An Update". Cureus 12 (2020): e7423.

12. E Hartenian., et al. "The molecular virology of coronaviruses". Journal of Biological Chemistry 295 (2020): 12910-12934.

13. R Wölfel., et al. "Virological assessment of hospitalized patients with COVID-2019”. Nature 581 (2020): 465-469.

14. Y Ishino., et al. "History of CRISPR-Cas from Encounter with a Mysterious Repeated Sequence to Genome Editing Technology". Journal of Bacteriology 200 (2018).

15. M Jinek., et al. "A programmable dual-RNA-guided DNA endonuclease in adaptive bacterial immunity". Science 337 (2012): 816-821.

16. K Sung., et al. "Target Specificity of Cas9 Nuclease via DNA Rearrangement Regulated by the REC2 Domain". Journal of the American Chemical Society 140 (2018): 7778-7781.

17. HY Kim., et al. "Chimeric crRNAs with 19 DNA residues in the guide region show the retained DNA cleavage activity of Cas9 with potential to improve the specificity". Chemical Communications 55 (2019): 3552-3555.

18. Z Liu., et al. "Application of different types of CRISPR/Casbased systems in bacteria". Microbial Cell Factories 19 (2020): 172.

19. B Wiedenheft., et al. "RNA-guided genetic silencing systems in bacteria and archaea". Nature 482 (2012): 331-338.

20. J Murovec., et al. "New variants of CRISPR RNA-guided genome editing enzymes". Plant Biotechnology Journal 15 (2017): 917926.

21. W Zhou., et al. "A CRISPR-Cas9-triggered strand displacement amplification method for ultrasensitive DNA detection". $\mathrm{Na}$ ture Communications 9 (2018): 5012.

22. H Yang., et al. "Methods Favoring Homology-Directed Repair Choice in Response to CRISPR/Cas9 Induced-Double Strand Breaks". International Journal of Molecular Sciences 21 (2020).
23. 00 Abudayyeh., et al. "C2c2 is a single-component programmable RNA-guided RNA-targeting CRISPR effector". Science 353 (2016): aaf5573-aaf5573.

24. M Lisboa Bastos., et al. "Diagnostic accuracy of serological tests for covid-19: systematic review and meta-analysis". BMJ 370 (2020): m2516.

25. K Pardee., et al. "Rapid, Low-Cost Detection of Zika Virus Using Programmable Biomolecular Components". Cell 165 (2016): 1255-1266.

26. M Azhar., et al. "Rapid, field-deployable nucleobase detection and identification using FnCas9". BioRxiv (2020).

27. N Rusk. "Spotlight on Cas12". Nature Methods 16 (2019): 215.

28. S-Y Li., et al. "CRISPR-Cas12a-assisted nucleic acid detection". Cell Discovery 4 (2018): 20.

29. JP Broughton., et al. "CRISPR-Cas12-based detection of SARSCoV-2". Nature Biotechnology 38 (2020): 870-874.

30. Z Ali., et al. "An RT-LAMP-coupled CRISPR-Cas12 module for rapid, sensitive detection of SARS-CoV-2". Virus Research 288 (2020): 198129.

31. X Ding., et al. "All-in-One Dual CRISPR-Cas12a (AIOD-CRISPR) Assay: A Case for Rapid, Ultrasensitive and Visual Detection of Novel Coronavirus SARS-CoV-2 and HIV virus". BioRxiv - The Preprint Server for Biology (2020).

32. LT Nguyen., et al. "Enhancement of trans-cleavage activity of Cas12a with engineered crRNA enables amplified nucleic acid detection". Nature Communication 11 (2020): 4906.

33. MJ Kellner., et al. "SHERLOCK: nucleic acid detection with CRISPR nucleases". Nature Protocols 15 (2020): 1311.

34. FZhang., et al. "A protocol for detection of COVID-19 using CRISPR diagnostics". Bio Archive (2020): 1-8.

35. JN Rauch., et al. "A Scalable, Easy-to-Deploy, Protocol for Cas13Based Detection of SARS-CoV-2 Genetic Material”. BioRxiv 59.4 (2020): e02402-02420.

36. CM Ackerman., et al. "Massively multiplexed nucleic acid detection with Cas13". Nature 582 (2020): 277-282.

37. TR Abbott., et al. "Development of CRISPR as an Antiviral Strategy to Combat SARS-CoV-2 and Influenza”. Cell 181 (2020): 865-876. 
38. TM Nguyen., et al. "Virus against virus: a potential treatment for 2019-nCov (SARS-CoV-2) and other RNA viruses". Cell Research 30 (2020): 189-190.

39. U Unniyampurath., et al. "RNA Interference in the Age of CRISPR: Will CRISPR Interfere with RNAi?" International Journal of Molecular Science 17 (2016): 291.

40. M Lotfi and N Rezaei. "CRISPR/Cas13: A potential therapeutic option of COVID-19". Biomedicine and Pharmacotherapy 131 (2020): 110738.

41. J Straiton. "CRISPR vs COVID-19: how can gene editing help beat a virus?" Biotechniques 69 (2020): 327-329.

42. Z Leng., et al. "Transplantation of ACE2 (-) Mesenchymal Stem Cells Improves the Outcome of Patients with COVID-19 Pneumonia". Aging and Disease 11 (2020): 216-228.

43. Golchin E., et al. "Mesenchymal Stem Cell Therapy for COVID-19: Present or Future". Stem Cell Reviews and Reports 16 (2020): 427-433.

44. Liang J., et al. "Clinical remission of a critically ill COVID-19 patient treated by human umbilical cord mesenchymal stem cells: A case report". Medicine (Baltimore) 99 (2020): e21429.

45. C-C Wu., et al. "CD146+ mesenchymal stem cells display greater therapeutic potential than CD146- cells for treating collagen-induced arthritis in mice". The Journal of Stem Cell Research and Therapy 7 (2016): 23.

46. DM Filho., et al. "Enhancing the Therapeutic Potential of Mesenchymal Stem Cells with the CRISPR-Cas System". Stem Cell Reviews and Reports 15 (2019): 463-473.

47. CA Freije., et al. "Programmable Inhibition and Detection of RNA Viruses Using Cas13". Molecular Cell 76 (2019): 826-837.

48. AL Askou., et al. "Retinal gene therapy: an eye-opener of the 21st century". Gene Therapy (2020).

49. J Parry. "Covid-19: Hong Kong scientists report first confirmed case of reinfection”. BMJ 370 (2020): m3340.

50. A Srivastava., et al. "Development of a new Collateral Cleavageindependent CRISPR/Cas12a based easy detection system for plant viruses". Journal of Virological Methods 300 (2022).

\section{Assets from publication with us}

- Prompt Acknowledgement after receiving the article

- Thorough Double blinded peer review

- Rapid Publication

- Issue of Publication Certificate

- High visibility of your Published work

Website: www.actascientific.com/

Submit Article: www.actascientific.com/submission.php

Email us: editor@actascientific.com

Contact us: +919182824667 